\title{
HUBUNGAN SELF-EFFICACY DENGAN KEPATUHAN MINUM OBAT ANTIRETROVIRAL (ARV) PADA PASIEN HIV-AIDS DI PUSKESMAS KOTA SORONG
}

\author{
Triani Banna*), Dirgantari Pademme**) \\ ${ }^{*}$ Sekolah Tinggi Ilmu Kesehatan (STIKES) Papua, Kota Sorong, email: 3anibanna@ gmail.com \\ ${ }^{* *}$ Sekolah Tinggi Ilmu Kesehatan (STIKES) Papua, Kota Sorong
}

\begin{abstract}
ABSTRAK
HIV-AIDS yang menyerang sistem imun manusia membuat tubuh tidak mampu untuk sembuh dari penyakit oportunistik dan mengarah ke kematian. Angka kejadian HIV-AIDS terus meningkat, baik secara nasional maupun secara global. Salah satu upaya pengendalian yang dilakukan adalah pemberian obat antiretroviral (ARV). Namun, angka kepatuhan minum obat ARV pada pasien HIV-AIDS masih belum mencapai target sasaran keberhasilan. Tujuan penelitian ini adalah untuk mengetahui hubungan self-efficacy dengan kepatuhan minum obat antiretroviral (ARV) pada pasien HIV-AIDS di Puskesmas Kota Sorong. Penelitian ini merupakan penelitian kuantitatif dengan metode analitik observasional dengan pendekatan cross-sectional. Penelitian dilakukan pada bulan Juni - Agustus 2019, terhadap 51 orang penderita HIV dan AIDS yang tergabung dalam kelompok dukungan sebaya (KDS) diambil dengan metode accidental sampling. Hasil penelitian menunjukkan bahwa $82.4 \%$ adalah perempuan, $84.3 \%$ berusia 17-45 tahun, 51\% didiagnosa HIV antara 1-5 tahun, 94.1\% pernah mendapatkan informasi tentang terapi ARV, dan 51\% aktif dalam pertemuan KDS. Uji Fisher menunjukkan terdapat hubungan antara self-efficacy dengan kepatuhan minum obat antiretroviral (ARV) pada pasien HIV-AIDS di Puskesmas Kota Sorong $(p=0,004)$. Disarankan kepada Pembina KDS maupun tenaga kesehatan yang terlibat dalam pengobatan pasien HIV-AIDS agar meningkatkan selfefficacy pasien dengan memberikan informasi tentang pengobatan ARV, dan lebih meningkatkan keaktifan pasien dalam KDS.
\end{abstract}

Kata Kunci: HIV-AIDS; Kepatuhan; ODHA; Terapi Antiretroviral; Self-efficacy

\begin{abstract}
HIV-AIDS attacks of immune system cells make the body can't recover from the opportunistic infection that often leads to death. The incidence of HIV-AIDS continues to increase, both nationally and globally. The use of multiple antiretroviral drugs is the control effort of HIV infection. However, the rate of adherence to ARV treatment in HIV-AIDS patients has not yet achieved targets. This study aimed to determine the relationship of self-efficacy with adherence to taking antiretroviral drugs (ARVs) in HIV-AIDS patients at the Sorong City Health Center. This study using a descriptive-analytic with a cross-sectional approach. The study was conducted from June to August 2019, a total of 51 people with HIV and AIDS who were members of a peer support group (KDS) were included by accidental technique. The results showed that $82.4 \%$ were women, $84.3 \%$ were aged $17-45$ years, $51 \%$ were diagnosed with HIV between $1-5$ years, $94.1 \%$ had received information about ARV therapy, and $51 \%$ were active in peer-group meetings. Fisher's test showed that there were significantly associated with self-efficacy and adherence to ARV among HIV-AIDS patients at the Sorong City Health Center $(p=0.004)$. It is recommended for peer counselors and health workers involved in the treatment of HIV-AIDS patients to increase patient self-efficacy by providing information about ARV treatment and to further increase the activity of patients in peer support groups.
\end{abstract}

Keywords: Adherence; Antiretroviral therapy; HIV-AIDS; PLWHA; Self-efficacy 


\section{PENDAHULUAN}

Penyebaran HIV dan AIDS diseluruh dunia termasuk Indonesia berkembang sangat pesat. Pada tahun 2017, jumlah penderita HIV mencapai 36,9 juta orang yang terdiri dari 35,1 juta orang dewasa dan 1,8 juta adalah anak berusia kurang dari 15 tahun. Data dari WHO menunjukkan bahwa tahun 2017 ODHA yang menerima terapi ARV berjumlah 21,7 juta orang (Unaids, 2018).

Jumlah penderita HIV tersebar di seluruh provinsi di Indonesia, tidak terkecuali Papua dan Papua Barat. Pada tahun 2017, Papua menduduki peringkat ke-5 jumlah penduduk terinfeksi HIV di Indonesia(Direktorat Jenderal Pencegahan dan Pengendalian Penyakit, 2017), Provinsi Papua Barat menduduki urutan ke-12 dengan persentase kumulatif 20\%. Sedangkan jumlah kasus HIV dan AIDS Kota Sorong sejak tahun 2004 sampai Juni 2017 sebanyak 1.697 orang kasus HIV dan 752 kasus AIDS, dan data kumulatif orang yang meninggal dunia akibat HIV dan AIDS sebanyak 310 orang(Dinas Kesehatan Kota Sorong, 2017).

Permasalahan medis yang dihadapi ODHA dapat berupa infeksi oportunistik (IO), gejala simtomatik yang berhubungan dengan AIDS, ko-infeksi, sindrom pulih imun tubuh serta efek samping dan interaksi obat ARV. Masalah psikologis yang mungkin timbul adalah depresi, ansietas (kecemasan), gangguan kognitif serta gangguan kepribadian sampai psikosis. Masalah sosial diantaranya diskriminasi, pengucilan, stigmatisasi, pemberhentian dari pekerjaan, perceraian, serta beban finansial yang harus ditanggung ODHA. Masalah tersebut tidak saja dihadapi oleh ODHA namun juga oleh keluarga dan kerabat dekatnya sehingga dapat berpengaruh terhadap kepuasan individu terhadap kehidupannya dan juga kualitas hidupnya(Dearly and Lestari, 2016).

Salah satu domain kualitas hidup pasien ODHA menurut WHO adalah kemandirian, yaitu bagaimana ODHA menjalani terapi ARV dengan patuh (Nursalam and Ninuk, 2013). Bagi ODHA, terapi ARV bukan hanya merupakan komponen utama dalam layanan medis, namun juga harapan untuk tetap hidup secara normal. Terapi ARV sangat diperlukan untuk membantu memulihkan imunitas sehingga dapat mengurangi kemungkinan IO, meningkatkan kualitas hidup, serta mengurangi kesakitan dan kematian(RI, 2012).

Puskesmas Kota Sorong merupakan fasilitas kesehatan yang memiliki akses sarana dan tenaga kesehatan sesuai standar yang ditetapkan dalam pelayanan HIV-AIDS. Sampai tahun 2017, jumlah ODHA yang mendapatkan terapi ARV pada puskesmas ini berjumlah 121 orang, meliputi anak, dewasa, sampai lansia. Hingga kini masalah yang sering terjadi di layanan VCT adalah ketidakpatuhan dalam minum obat ARV secara teratur dan tepat dosis.

Pasien HIV positif yang sudah memulai terapi ARV pada puskesmas ini memiliki kepatuhan yang bervariasi, diakibatkan tidak adanya pengawas minum obat dan keterbatasan fisik pasien. Faktor psikologi pasien serta dukungan sosial juga merupakan determinan yang turut menghambat pasien untuk tepat waktu dalam pengobatan, dalam hal ini adalah selfefficacy. Tingkat self-efficacy dapat mempengaruhi usaha yang dilakukan seseorang untuk mencapai perilaku yang ditargetkan dan berdampak pada kemampuan individu untuk tetap melakukan aktifitas dalam menghadapi hambatan atau kegagalan.

Secara psikologis, self-efficacy memiliki peranan promotif yang penting dalam kesehatan, yaitu mempengaruhi fase perubahan individu diantaranya memulai usaha untuk mengubah kebiasaan, pengerahan pengaruh dalam diri untuk mencapai keberhasilan, dan mempertahankan perubahan kebiasaan yang telah dicapai (Bandura, 1995). Self-efficacy merupakan hal yang penting untuk dimiliki oleh pasien penyakit kronik, tidak terkecuali ODHA. Dengan demikian, urgensi dilakukannya penelitian ini adalah ditemukannya hasil penelitian yang dapat menjadi dasar dalam pengembangan kebijakan selanjutnya pada tatanan pengambil kebijakan, maupun pengembangan model maupun pendekatan yang dapat digunakan untuk meningkatkan kepatuhan pasien dalam menjalani terapi ARV.

\section{BAHAN DAN METODE}

Penelitian ini merupakan penelitian kuantitatif dengan metode analitik observasional dengan pendekatan crosssectional. Penelitian dilakukan pada bulan Juni - Agustus 2019 terhadap 51 orang 
penderita HIV dan AIDS yang tergabung dalam kelompok dukungan sebaya (KDS) dengan memperhatikan prinsip dan etika penelitian (Polit and Beck, 2007). Pengambilan sampel dilakukan dengan metode accidental sampling. Data dikumpulkan menggunakan kuesioner selfefficacy HIV, dan MMAS-8 Morisky Medication Adherence Scale).

\section{HASIL}

Hasil penelitian yang menunjukkan karakteristik responden dan gambaran variabel penelitian dapat dilihat pada tabel 1 berikut:

\section{Tabel 1}

\section{Karakteristik Responden}

\begin{tabular}{lcc}
\hline $\begin{array}{c}\text { Karakteristik } \\
\text { Responden }\end{array}$ & $\begin{array}{c}\text { Jumlah } \\
\text { (n) }\end{array}$ & $\begin{array}{c}\text { Persentase } \\
(\%)\end{array}$ \\
\hline Umur & & \\
< 17 tahun & 2 & 3.9 \\
$17 \quad-\quad 45$ & 43 & 84.3 \\
tahun & 6 & 11.8 \\
$\quad>45$ tahun & & \\
Jenis Kelamin & & \\
Laki-laki & 9 & 17.6 \\
$\quad$ Perempuan & 42 & 82.4 \\
Pendidikan & & \\
SD & 13 & 25.5 \\
SMP & 9 & 17.6 \\
SMA & 26 & 51.0 \\
Perguruan & 3 & 5.9 \\
Tinggi & & \\
Informasi & & \\
Pengobatan HIV & & \\
Ya & 48 & 94.1 \\
Tidak & 3 & 5.9 \\
Lama Mengikuti & & \\
KDS & & \\
< 1 tahun & 16 & 31.4 \\
1-5 tahun & 26 & 51.0 \\
$>$ 5 tahun & 9 & 17.6 \\
& & \\
Seberapa sering & & \\
ikut KDS & & \\
Selalu & 41 & \\
Kadang- & 10 & 19.6 \\
kadang & & \\
\hline
\end{tabular}

Berdasarkan tabel 1 di atas dapat diketahui bahwa responden pada penelitian ini lebih banyak yang berusia $17-45$ tahun $(84.3 \%)$, berjenis kelamin perempuan (82.4\%), berpendidikan SMA (51\%). Sedangkan bila dilihat dari keterpaparan pasien terhadap informasi pengobatan ARV didapatkan bahwa $48 \%$ responden pernah mendapatkan informasi tentang pengobatan, $51 \%$ responden mengikuti Kelompok Dukungan Sebaya (KDS) 1-5 tahun, dan yang selalu mengikuti tiap KDS $80.4 \%$.

Hubungan antar variabel disajikan pada tabel 2 berikut:

\section{Tabel 2}

Hubungan self-efficacy dengan kepatuhan minum obat antiretroviral (ARV) pada pasien HIV-AIDS di Puskesmas Kota Sorong

\begin{tabular}{|c|c|c|c|c|c|c|c|}
\hline \multirow{3}{*}{$\begin{array}{c}\text { Self- } \\
\text { efficac } \\
y\end{array}$} & \multicolumn{4}{|c|}{ Kepatuhan } & \multicolumn{2}{|c|}{ Total } & \multirow[t]{2}{*}{$\begin{array}{c}\text { nila } \\
\text { i p } \\
\end{array}$} \\
\hline & \multicolumn{2}{|c|}{$\begin{array}{l}\text { Tidak } \\
\text { Patuh }\end{array}$} & \multicolumn{2}{|c|}{ Patuh } & & & \\
\hline & n & $\%$ & n & $\%$ & n & $\%$ & \\
\hline Rendah & 4 & 80 & 1 & 20 & 5 & 10 & \\
\hline Tinggi & 6 & 13 & $\begin{array}{l}4 \\
0\end{array}$ & 87 & $\begin{array}{l}4 \\
6\end{array}$ & $\begin{array}{c}0 \\
10\end{array}$ & $\begin{array}{c}0.00 \\
4\end{array}$ \\
\hline Total & $\begin{array}{l}1 \\
0\end{array}$ & $\begin{array}{c}19 . \\
6\end{array}$ & 1 & $\begin{array}{c}80 . \\
4\end{array}$ & $\begin{array}{l}5 \\
1\end{array}$ & $\begin{array}{c}0 \\
10 \\
0\end{array}$ & \\
\hline
\end{tabular}

Berdasarkan tabel 2 dapat dilihat bahwa responden yang memiliki self-efficacy rendah dan tidak patuh sebanyak $80 \%$, walaupun $20 \%$ responden lainnya patuh terhadap regimen terapi. Sedangkan responden yang memiliki self-efficacy tinggi dan tidak patuh sebanyak 13\%, namun $87 \%$ responden menunjukkan kepatuhan terhadap regimen terapi. Hasil uji Fisher menunjukkan nilai $\mathrm{p}=$ 0.004 , berarti ada hubungan antara selfefficacy dengan kepatuhan minum obat antiretroviral (ARV) pada pasien HIV-AIDS di Puskesmas Kota Sorong.

\section{PEMBAHASAN}

Berdasarkan hasil penelitian yang dapat dilihta pada tabel 2, didapatkan bahwa ada hubungan antara antara self-efficacy dengan kepatuhan minum obat antiretroviral (ARV) pada pasien HIV-AIDS di Puskesmas Kota Sorong.

Kepatuhan adalah derajat dimana 
pasien mengikutti anjuran klinis dari dokter yang mengobatinya sejauh mana perilaku pasien sesuai dengan ketentuan yang diberikan oleh profesional kesehatan. Kepatuhan berarti memakai obat persis sesuai aturan yaitu obat yang benar, waktu yang benar dengan cara yang benar mengobati infeksi HIV dengan obat-obatan. ARV tidak membunuh virus HIV, namun dapat memperlambat pertumbuhan virus, waktu pertumbuhan virus diperlambat, begitu juga penyakit HIV.

Kepatuhan (adherence) pada terapi adalah sesuatu keadaan dimana pasien mematuhi pengobatannya atas dasar kesadaran sendiri, bukan hanya karena mematuhi perintah dokter. Kepatuhan harus selalu dipantau dan dievaluasi secara teratur pada setiap kunjungan. Kegagalan terapi ARV sering diakibatkan oleh ketidakpatuhan pasien mengkonsumsi ARV. Untuk mencapai supresi virologis yang baik diperlukan tingkat kepatuhan terapi ARV yang sangat tinggi. Penelitian menunjukkan bahwa untuk mencapai tingkat supresi virus yang optimal, setidaknya 95\% dari semua dosis tidak boleh terlupakan (Kementerian Kesehatan Republik Indonesia, 2011, 2015).

Dampak ketidakpatuhan pasien dalam mengkonsumsi ARV dapat mempengaruhi jumlah CD4 yang ada di tubuh. Jika CD4 menurun sampai $200 \mathrm{sel} / \mathrm{ml}$ sistem kekebalan tubuh tidak dapat bekerja dengan optimal, sehingga lebih mudah terkena IO. Resistensi juga terjadi dikarenakan adanya kegagalan pengobatan ARV yang salah satu faktor penyebabnya yaitu ketidakpatuhan terhadap terapi yang sedang dijalani. Selain itu juga adanya depresi dan kurangnya dukungan dari keluarga terhadap pasien menimbulkan kegagalan terapi (Fajar, 2013).

Self-efficacy didefinisikan sebagai penilaian seseorang terhadap kemampuannya untuk mengatur dan melaksanakan program tindakan yang diperlukan untuk mencapai jenis tindakan yang ingin dilakukan, termasuk mengenai kesehatan (Bandura, 1995). Kepercayaan seseorang mengenai efficacy-nya juga memiliki peranan promotif yang penting dalam kesehatan, dan mempengaruhi tiga fase perubahan individu, yaitu memulai usaha untuk mengubah kebiasaannya, pengerahan pengaruh dalam diri yang dibutuhkan untuk mencapai keberhasilan, dan mempertahankan perubahan kebiasaan yang telah dicapai.

Tingkat self-efficacy dapat mempengaruhi usaha yang dilakukan seseorang untuk mencapai perilaku yang ditargetkan dan berdampak pada kemampuan individu untuk tetap melakukan aktifitas dalam menghadapi hambatan atau kegagalan (Bandura, 1995; Kolmodin Macdonell et al., 2016).

Karakteristik responden pada tabel 1 menunjukkan bahwa self-efficacy responden pada penelitian ini cenderung tinggi, demikian pula perilaku kepatuhan terhadap pengobatan. Hal ini dianggap sejalan dengan hasil analisis bivariat yang menunjukkan hubungan antara self-efficacy dengan kepatuhan minum obat antiretroviral (ARV) pada pasien HIV-AIDS. Berdasarkan hasil tersebut dapat dikatakan bahwa peningkatan self-efficacy dapat meningkatkan pula kepatuhan pasien dalam pengobatan.

Bila didasarkan pada hasil analisis karakteristik responden, dapat dilihat bahwa ada beberapa karakteristik pasien yang mendukung juga hasil tersebut, diantaranya sebagian besar responden sudah pernah terpapar informasi tentang pengobatan, mengikuti kegiatan KDS 1-5 tahun, dan selalu aktif mengikuti kegiatan tersebut. Melalui kegiatan KDS pasien mendapatkan informasi yang cukup sehingga dapat meningkatkan pengetahuan dan keyakinan mereka untuk dapat menjalani terapi dengan baik, dan sesuai.

Karakteristik pasien berdasarkan jenjang pendidikan memperlihatkan bahwa sebagian besar dari responden memiliki jenjang pendidikan menengah atas dan pendidikan tinggi. Pendidikan formal yang didapatkan melalui sekolah dapat mendukung pada proses pembentukan self-efficacy. Pada proses pendidikan di sekolah, individu akan dapat mengembangkan kemampuan kognitif, afektif, dan psikomotor. Ketiga ranah ini berperan penting dalam pengembangan pola pikir dan nilai-nilai yang dimiliki seseorang mengenai suatu hal, bagaimana menyikapinya, dan kemudian pengembangan keterampilan atau ketepatan bertindak sesuai dengan informasi yang didapatkan. Selfefficacy yang telah terbentuk dapat mendukung perubahan perilaku individu, sehingga diharapkan pasien dapat memiliki kepatuhan yang tinggi terhadap pengobatan, meskipun diketahui selain berdampak positif 
terhadap penurunan viral load, banyak juga dampak kurang mengenakkan yang akan dialami oleh pasien yang mengkonsumsi ARV (Adefolalu et al., 2014).

\section{SIMPULAN DAN SARAN Simpulan}

Kesimpulan dari penelitian ini adalah ada hubungan antara antara self-efficacy dengan kepatuhan minum obat antiretroviral (ARV) pada pasien HIV-AIDS di Puskesmas Kota Sorong.

\section{Saran}

Disarankan kepada Pembina KDS maupun tenaga kesehatan yang terlibat dalam pengobatan pasien HIV-AIDS agar meningkatkan self-efficacy pasien dengan memberikan informasi tentang pengobatan ARV, dan lebih meningkatkan keaktifan pasien dalam KDS.

\section{KEPUSTAKAAN}

Adefolalu, A. et al. (2014) 'Self-efficacy, medication beliefs and adherence to antiretroviral therapy by patients attending a health facility in Pretoria', South African Family Practice. Cogent, 56(5), pp. 281285. doi: 10.1080/20786190.2014.975476.

Bandura, A. (ed.) (1995) Self-Efficacy in Changing Societies. Cambridge University Press.

Dearly and Lestari, S. (2016) 'HUBUNGAN ANTARA SELF EFFICACY DENGAN SUBJECTIVE WELL BEING PADA ORANG DENGAN HIV / AIDS DI JAKARTA', Jurnal Ilmu Ekonomi dan Sosial, 5(3), pp. 258-264.

Dinas Kesehatan Kota Sorong (2017) Profil Kesehatan dan Data Situasi Kasus HIV dan AIDS Tahun 2017.

Direktorat Jenderal Pencegahan dan Pengendalian Penyakit (2017) Laporan Perkembangan HIV/AIDS 7 Penyakit Menular Seksual (PIMS) Triwulan I Tahun 2017, Perkembangan HIV_AIDS \& PIMS di Indonesia Januari-Maret 2017.

Fajar, A. (2013) Hubungan Antara Stadium Klinis, Viral Load, dan Jumlah CD4 Pada Pasien HIV dan AIDS di RSUP DR. Kariadi Semarang. Universittas Diponegoro.

Kementerian Kesehatan Republik Indonesia (2011) Pedoman Nasional Tatalaksana
Klinis Infeksi HIV dan Terapi Antiretroviral. Jakarta: Direktoral Jendral Pengendalian Penyakit dan Penyehatan Lingkungan.

Kementerian Kesehatan Republik Indonesia (2015) Peraturan Menteri Kesehatan Republik Indonesia Nomor 87 Tahun 2014 Tentang Pedoman Pengobatan Antiretroviral, Kementerian Kesehatan RI.

Kolmodin Macdonell, K. et al. (2016) 'Predictors of Self-Reported Adherence to Antiretroviral Medication in a Multisite Study of Ethnic and Racial Minority HIVPositive Youth', Journal of Pediatric Psychology, 41(4), pp. 419-428. doi: 10.1093/jpepsy/jsv097.

Nursalam and Ninuk, D. K. (2013) Asuhan Keperawatan Pada Pasien Terinfeksi HIV/AIDS. Jakarta: Salemba Medika.

Polit, D. F. and Beck, C. T. (2007) Nursing Research. 7th edn. Philadelphia: Lippincott Williams \& Wilkins.

RI, K. K. (2012) Pedoman Penerapan Layanan Komprehensif HIV-AIDS Berkesinambungan. Jakarta: Dirjen P2PL.

Unaids (2018) UNAIDS Global statistics 2018. Available at: http://www.unaids.org/sites/default/files/ media_asset/UNAIDS_FactSheet_en.pdf. 